University of Nebraska - Lincoln

DigitalCommons@University of Nebraska - Lincoln

1986

\title{
Age of the Earliest African Anthropoids
}

John G. Fleagle

State University of New York

Thomas M. Bown

United States Geological Survey

John D. Obradovich

United States Geological Survey

Elwyn L. Simons

DukeUniversity, esimmons@duke.edu

Follow this and additional works at: https://digitalcommons.unl.edu/usgsstaffpub

Part of the Earth Sciences Commons

Fleagle, John G.; Bown, Thomas M.; Obradovich, John D.; and Simons, Elwyn L., "Age of the Earliest African Anthropoids" (1986). USGS Staff -- Published Research. 210.

https://digitalcommons.unl.edu/usgsstaffpub/210

This Article is brought to you for free and open access by the US Geological Survey at DigitalCommons@University of Nebraska - Lincoln. It has been accepted for inclusion in USGS Staff -- Published Research by an authorized administrator of DigitalCommons@University of Nebraska - Lincoln. 


\title{
Age of the Earliest African Anthropoids
}

\author{
John G. Fleagle, Thomas M. Bown, John D. Obradovich, \\ ELWYN L. SIMONS
}

The earliest fossil record of African anthropoid primates (monkeys and apes) comes from the Jebel Qatrani Formation in the Fayum depression of Egypt. Reevaluation of both geologic and faunal evidence indicates that this formation was deposited in the early part of the Oligocene Epoch, more than 31 million years ago, earlier than previous estimates. The great antiquity of the fossil higher primates from Egypt accords well with their primitive morphology compared with later Old World higher primates. Thus, the anthropoid primates and hystricomorph rodents from Fayum are also considerably older than the earliest higher primates and rodents from South America.

$\mathrm{T}$ HE EARLIEST ANTHROPOID PRImates of Africa come from extensive early Tertiary deposits in the Fayum depression of Egypt, approximately $100 \mathrm{~km}$ southwest of Cairo. From their initial discovery in the beginning of the century, the fossil primate species from this area have played a critical role in our understanding of anthropoid origins and the evolution of monkeys, apes, and humans (1-3). Moreover, the Fayum provides the best record of Paleogene mammals from all of Africa and is critical for understanding the evolution of many mammalian groups on that continent including marsupials, pangolins, elephant shrews, bats, insectivorans, creodonts, hyracoids, elephants, anthracotheres, embrithopods, and hystricomorph rodents. Knowledge of the age of the Fayum deposits is critical for calibrating early aspects of higher primate evolution and for understanding the biogeography and evolution of many other mammals $(4,5)$.

The preponderance of apparently endemic African elements in the Fayum mammalian fauna, however, precludes precise faunal correlation between the Fayum and other paleontological localities that could place this fauna in a worldwide chronological framework. Comparison of the Fayum mammals with Eocene and Oligocene mammals from Eurasia showed only three common genera (Peratherium, Pterodon, and Apterodon) and five common families. All faunal comparisons indicated that the Egyptian fossils were most comparable to late Eocene and early Oligocene taxa from Europe, but sufficiently distinct that a more precise correlation was impossible (6).

All the Fayum primates and most of the terrestrial mammals have come from the fluvial Jebel Qatrani Formation (Fig. 1), which conformably overlies the nearshore marine and fluvial Qasr el Sagha Formation. The Jebel Qatrani Formation is comprised of $340 \mathrm{~m}$ of variegated alluvial rocks and fine to coarse sandstones, conglomerates, sandy mudstones, carbonaceous mudstones, and limestones, all of which show evidence of profound mechanical and geochemical alteration due to ancient soil (paleosol) formation. Vertebrate fossils have been recovered from dozens of localities throughout the formation (Fig. 1).

The Jebel Qatrani Formation is a complex alluvial unit characterized by distinct largeand small-scale lateral and vertical facies changes (7). In general, deposition was by meandering streams. Local, small-scale changes in lithology reflect shifting from one local channel environment to another and transitions from channel to floodplain deposits. The Jebel Qatrani lithotope was low and had little relief. The occasional occurrence of sirenians and brackish water mollusks, sharks, and rays suggests that storms, tidal incursions, or both, increased the salinity of the streams for several kilometers inland. The flood basins of the Jebel Qatrani streams were apparently heavily vegetated in many areas, as evidenced by numerous fossil root casts and areas with abundant fossil trees. There were areally large, but shallow and probably ephemeral, nonsaline ponds; soils were generally damp with probably seasonal rainfall.

The fossil megafloras show affinities with present-day tropical Indomalaysian floras. They suggest a "tropical forest existing in a wet, perhaps monsoonal climate" (5). Like the paleoflora, the soils indicate seasonal wetness with good drainage in some areas and swampy conditions in others.

Inasmuch as neither the sedimentary rocks nor the mammalian fauna of the Jebel Qatrani Formation provide precise evidence regarding the age of the formation, the best evidence for the age of this formation and the primates found there comes from the respective ages of the immediately overlying and underlying rocks - the Widan el Faras Basalt above and the partly marine and partly fluvial Qasr el Sagha Formation below.

In the Fayum depression, the upper Qatrani escarpment is capped by 2 to $25 \mathrm{~m}$ of the Widan el Faras Basalt, a dark, densely aphanitic, iron-rich extrusive basalt that is exposed for over $50 \mathrm{~km}$. In outcrops where the basalt is thinnest, it appears to be a single flow; however, weathered and scorched contacts within the basalt as well as lenses of gravelly sand containing basaltic clasts attest to the presence of at least two and probably three separate flows over much of the area of exposure. The flows overlie the Jebel Qatrani Formation with a pronounced erosional unconformity, evidenced locally by broad scours of up to $25 \mathrm{~m}$ in depth. The thickness, and even the presence of individual flows, is controlled by the topographic irregularities at the top of the Jebel Qatrani Formation. In places where the basalt flows are absent, the Jebel Qatrani Formation is

J. G. Fleagle, Department of Anatomical Sciences Health Sciences Center, State University of New York, Stony Brook, NY 11794.

T. M. Bown and J. D. Obradovich, United States T. M. Bown and J. D. Obradovich
Geological Survey, Denver, CO 80225 . E. L. Simons, Duke University, Durham, NC 27705. 
overlain unconformably by the alluvial $\mathrm{Ka}$ shab Formation of lower Miocene age.

Earlier, Simons $(8)$ reported K-Ar ages of $24.7 \pm .4$ and $27.0 \pm 3.0$ million years for two samples of the Widan el Faras Basalt collected in the area between Widan el Faras and Tel Beadnell (where the flow is relatively thick). It is uncertain exactly where within the basalt these samples were obtained; however, they are almost certainly from basalts higher in the local paleotopography than a new sample collected in 1981 from $70 \mathrm{~cm}$ above the base of the lowest flow west-northwest of Widan el Faras. This sample was dated by one of us (J.D.O.) and yielded an age of $31.0 \pm 1.0$ million years (6). The two younger ages either were on rocks obtained from different flows higher in the basalt or were determined on partially altered samples.

The age of 31 million years for the lowest part of the Widan el Faras Basalt provides a minimum age for the underlying Jebel Qa-

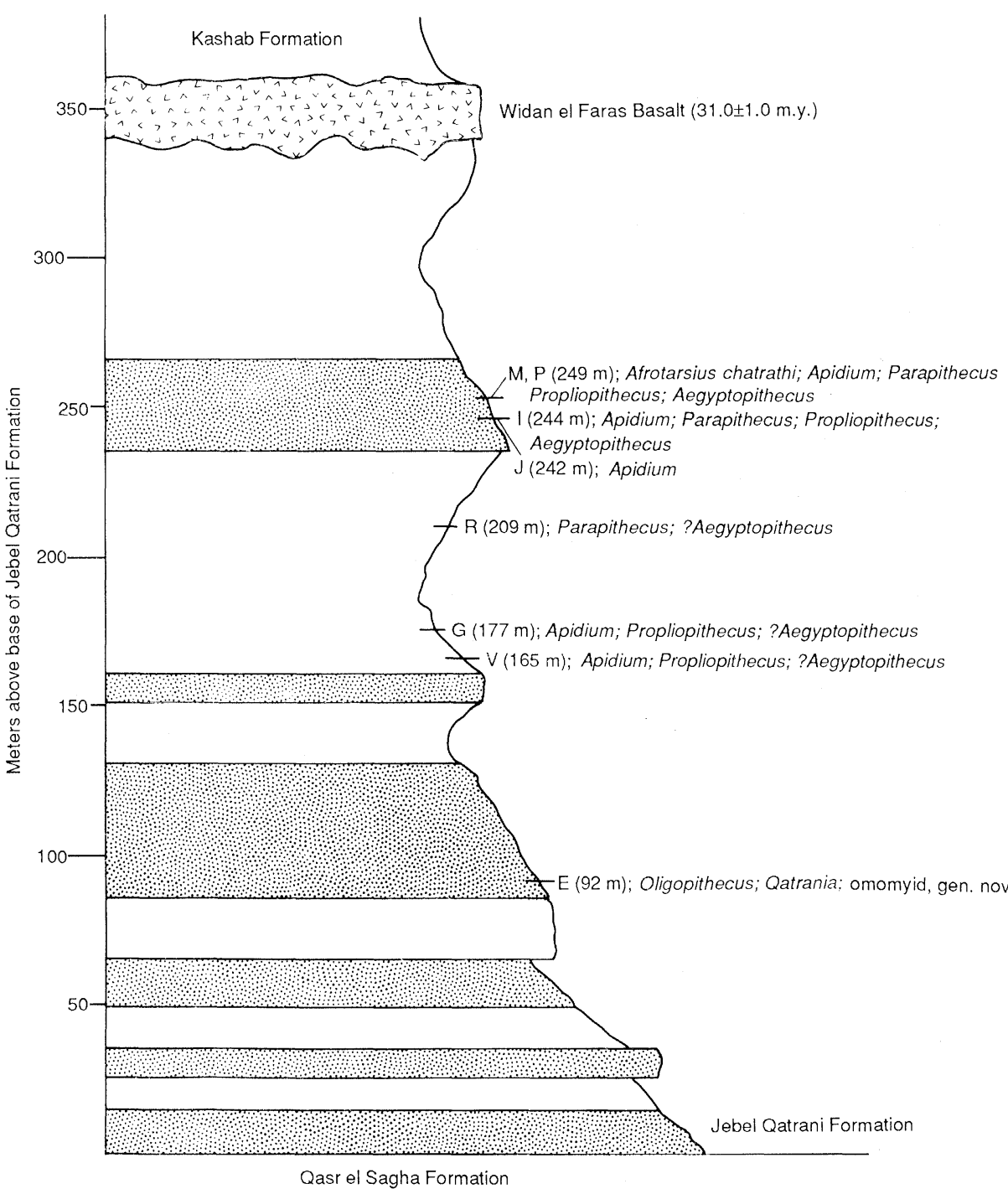

Fig. 1. Schematic stratigraphic section of the Jebel Qatrani Formation showing relations with other formations in the Fayum depression and the distribution of fossil primate taxa within the geological section. Capital letters designate fossil vertebrate quarry sites. est undoubted higher primates $(11)$ and have generally been regarded as broadly ancestral to the younger fossil apes from the Miocene of Europe, East Africa, and Asia. However, there has been considerable debate concerning the phyletic relationships of the various Fayum primates with regard to the evolutionary divergence of later lineages leading to Old World monkeys, lesser apes, and hominids. When the Fayum "apes" Propliopithecus and Aegyptopithecus were known almost totally from fragmentary dental remains, individual species of Oligocene "apes" seemed to mark the evolutionary divergence of lineages leading to gibbons, great apes, and possibly even hominids. At the same time, the lineage leading to the living Old World monkeys seemed to be present in the sympatric and synchronous parapithecids (2).

More complete fossil material has brought increasing evidence that the early "apes" from the Fayum are extremely primitive with respect to living catarrhines (3). Although they share with living catarrhines a reduced dental formula with two premolars, Aegyptopithecus and Propliopithecus retain more primitive, platyrrhine-like features in many aspects of cranial and postcranial anatomy and certainly precede the monkey-ape divergence.

Compared with the Fayum anthropoids, the higher primates from the early Miocene of Kenya are more advanced morphologically and more similar to living catarrhines. Although there is debate regarding the precise relationship of the Proconsul group to living apes, they have all the features that characterize living catarrhines and a few distinctly ape-like characters (12). Similarly, the early Miocene monkeys from Napak and Buluk clearly document the presence of cercopithecoids in East Africa between 15 and 20 million years ago (13).

Thus, there appears to be a considerable morphological gap between the early anthropoids of the Fayum and the monkeys and apes of the early Miocene of East Africa. The former show only a few features that distinguish them from a generalized higher primate condition, whereas the latter document the divergence of lineages leading to living cercopithecoids and hominoids. In light of the revised minimum age of the Jebel Qatrani Formation we realize that this morphological gap corresponds to a substantial temporal gap of more than 10 million years between the two groups of fossil anthropoids. At present, we have virtually no evidence of anthropoid evolution between 30 and 20 million years ago, the time of a major adaptive radiation of catarrhines and probably the phyletic divergence of monkeys and apes. 
Some authorities have suggested that, because of their many primitive anthropoid characteristics, one group of Fayum primates, the parapithecids, may be related to the New World platyrrhines (14). A major line of evidence against an African origin for platyrrhines has been the apparent differences in the relative age of the earliest African and South American anthropoids. Earlier correlations placed the earliest platyrrhines at 35 million years ago, nearly 10 million years older than the supposed age of the Fayum primates. However, more recent studies of the geology of the Salla basin in Bolivia (15) have shown that the earliest platyrrhines are probably from about 25 million years ago, substantially younger than the Fayum anthropoids. Thus, the new minimum age estimate of the Jebel Qatrani Formation indicates that the Fayum primates are substantially older than the first appearances of all modern anthropoid radia- tions, a chronology that accords well with morphological analyses that place some species at the base of the higher primate radiation.

\section{REFERENCES AND NOTES}

1. M. Schlosser, Paleontol. Geol. Ost.Ung. Orient. Bietr. 2, 24 (1911).

2. E. L. Simons, Primate Evolution (Macmillan, New York, 1972)

3. J. G. Fleagle and R. F. Kay, in New Interpretations of Ape and Human Ancestry, R. L. Ciochon and R. S. Corruccini, Eds. (Plenum, New York, 1983), pp. 181-210.

4. V. Maglio and H. B. S. Cooke, Eds., Evolution of African Mammals (Harvard Univ. Press, Cambridge, $19 ; \rightarrow$ T. M. Bown and E. L. Simons, Nature (London) 308, 447 (1984)

$\Rightarrow$ T. M. Bown et al., J. Hum. Evol. 11, 603 (1982)

6. J. G. Fleagle, T. M. Bown, J. D. Obradovich, E. L. Simons, in Primate Evolution, J. G. Else and P. C. Lee, Eds. (Cambridge Univ. Press, Cambridge, Lee, Eds. (Cam

7. T. M. Bown and M. J. Kraus, U.S. Geol. Surv. Prof. Pap., in press.

8. E. L. Simons, Sci. Am. 217, 28 (December 1967);

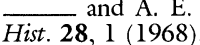

W. A. Berggren, D. V. Kent, J. J. Flynn, J. A. Van Couvering, Geol. Soc. Am. Bull. 96, 1407 (1985).

10. R. Said, The Geology of Egypt (Elsevier, Amsterdam, 1962).

11. The higher primate status of the still poorly known Burmese primates Amphipithecus and Pondaungia [R. L. Ciochon, D. E. Savage, T. Tint, B. Maw, Re. L. Ciochon, D. E. Savage, T. T
Science 229, 756 (1985)] is unsettled.

12. P. Andrews, in Ancestors: The Hard Evidence, E. Delson, Ed. (Liss, New York, 1985), pp. 14-22.

$\rightarrow$ D. Pilbeam and A. Walker, Nature (London) 220 657 (1968); M. Leakey, Folia Primatol. 44, (1985).

14. V Sarich, in Old World Monkeys, J. R. Napier and P. H. Napier, Eds. (Academic Press, London, 1970), pp. 195-196; R. Hoffstetter, Bull. Mem. Soc. An thropol. Paris 4, 927 (1977).

15. B. J. MacFadden et al., J. Geol. 93, 223 (1985); B. J. MacFadden, J. Vert. Paleontol. 5, 169 (1985).

16. We thank the Geological Survey of Egypt for assistance and cooperation, especially B. Issawi, R. Eissa, B. el-Khashab, A. A. el Awady Kandil, A. el Ghany Ibrihim Shellaby, and M. Askalany; and M. Kraus, P. Chatrath, D. Domning, T. Rasmussen, P. Gin gerich, R. Kay, S. Wing, and D. Krause for information and suggestions. Supported in part by BNS 8310913 , BNS 8546024 and BNS 8521655 , from NSF and 70869600 and 809479 from the Smithsonian Foreign Currency Pro sonian Foreign Currency Program Duke Primate Center publication 415 .

14 July 1986; accepted 10 October 1986 